does not corrode. There would appear to be no toxicity hazard for the patient from dental amalgam restorations. In fact the rapid rate of polarization of the different corrosion reactions in dental amalgam suggests that corrosion is somewhat beneficial in that the marginal gap between the restoration and tooth is sealed by the formation of corrosion products of limited solubility.

Department of Dental Materials,

J. A. von Fraunhofer

P. J. STAhel

Institute of Dental Surgery,

University of London

${ }^{1}$ Ryge, G., Fairhurst, C. W., and Fischer, C. M., Int. Dent. J., 11, 181 (1961).

${ }^{2}$ Wing, G., and Ryge, G., J. Dent. Res., 44, 1325 (1965).

3 Wing, G., Aust. Dent. J., 11, 105 (1966).

4 Allan, F., Asgar, K., and Peyton, F., J. Dent. Res., 44, 1002 (1965).

5 Jorgensen, K. D., Acta Odont. Scand., 23, 347 (1965).

6 Schoonover, I. C., and Souder, W., J. Amer. Dent. Ass., 28, 1278 (1941).

${ }^{7}$ Schriever, W., and Diamond, L. E., J. Dent. Res., 31, 205 (1952).

8 Mumford, J. M., Br. Dent. J., 94, 256 (1953).

9 Mumford, J, M., J. Dent. Res., 36, 632 (1957)

${ }_{10}$ Mumford, J. M., Br. Dent. J., 108, 299 (1960).

11 Fusayama, T., Katayori, T., and Nomoto, S., J. Dent. Res., 42, 1183 (1963)

12 Guthrow, C. E., Johnson, L. B., and Lawless, K. R., J. Dent. Res., 46, 1372 (1967)

${ }^{13}$ Carter, D., Ross, T., and Smith, D., Br. Corros. J., 2, 199 (1967).

14 von Fraunhofer, J. A., and Staheli, P. J., Br. Dent. J., 130, 522 (1971).

15 von Fraunhofer, J. A., and Staheli, P. J., Br. Dent. J., 132, 357 (1972).

16 Jenkins, G. N., The Physiology of the Mouth, third edition, 317 (Oxford, Blackwell, 1967).

\section{Dutch Elm Disease-Recurrence and Recovery in Britain}

SuRveys ${ }^{1}$ of Dutch elm disease in Britain between 1928 and 1955 suggested that native elms attacked by the disease very frequently recovered, even when a large part of the crown was these, no evidence of new beetle attack could be found and disease recurrence was thought probable.

Assessments in July 1972 on various elm species inoculated in June 1971 with aggressive and non-aggressive isolates of C. ulmi yielded further information on recurrence. All inoculated elms showed symptoms of the disease in 1971; those inoculated with the aggressive strain showed the more severe symptoms. No scolytid beetles were present as vectors of the disease in either 1971 or 1972 . The results of assessment of disease recurrence in 1972 are shown in Table 1.

The disease has recurred in all species of elm tested $(U$. glabra, $U$. carpinifolia and $U$. americana), and of the sixteen cases of recurrence, fifteen occurred with the aggressive strain. The one case of recurrence with the non-aggressive strain may have been aided by knife cuts made into the tree early in 1972, allowing the fungus to pass from one annual ring to the next.

Preliminary histological examination of stem sections from the inoculated trees showed that staining of the vascular tissue extended at least to the root collar with both strains of the fungus. A greater proportion of the 1971 annual ring was affected by the aggressive strain, which was much narrower as a result of more extensive crown dieback. The chances of cross-over from the 1971 to the 1972 aniual ring may well have been greater with the aggressive strain. The exact location of the cross-over in these trees has yet to be determined. The passage of the disease from one year to the next withun the tree provides a means of carry-over in the absence of the beetle. This may allow an epidemic to continue even in seasons of low insect activity.

In Britain recurrence of the disease after initial attack may have become more frequent in recent years, and this may be associated with the presence of the aggressive strain. This suggestion is supported by data from the 1971 Forestry Commission Survey ${ }^{4}$ which showed that there was little sign of recovery from the disease apparent in the severe outbreak areas.

These observations may have considerable significance in the future development of the epidemic and in measures taken towards its control. In the present sanitation felling programme it is recommended that those trees with more than half the crown affected by the disease should be felled and the bark

Table 1 Assessment of Recurrence of Dutch Elm Disease in Various Elm Species

\begin{tabular}{|c|c|c|c|c|c|}
\hline Species & $\begin{array}{l}\text { Age in } \\
1972\end{array}$ & Strain of C.ulmi & $\begin{array}{l}\text { No. of trees } \\
\text { inoculated } \\
\text { June } 1971\end{array}$ & $\begin{array}{c}\text { No. of trees } \\
\text { alive } \\
\text { July } 1972\end{array}$ & $\begin{array}{l}\text { No. of trees } \\
\text { with recurrence } \\
\text { July } 1972\end{array}$ \\
\hline U. glabra (seedlings) & $5 \mathrm{yr}$ & $\begin{array}{l}\text { Aggressive } \\
\text { Non-aggressive }\end{array}$ & $\begin{array}{l}35 \\
35\end{array}$ & $\begin{array}{l}31 \\
35\end{array}$ & $\begin{array}{l}8 \\
1\end{array}$ \\
\hline$U$. carpinifolia (Cornish elm) (rooted cuttings) & $6 \mathrm{yr}$ & $\begin{array}{l}\text { Aggressive } \\
\text { Non-aggressive }\end{array}$ & $\begin{array}{l}7 \\
7\end{array}$ & $\begin{array}{l}7 \\
7\end{array}$ & $\begin{array}{l}4 \\
0\end{array}$ \\
\hline U. carpinifolia (Wheatley elm) (rooted cuttings) & $6 \mathrm{yr}$ & $\begin{array}{l}\text { Aggressive } \\
\text { Non-aggressive }\end{array}$ & $\begin{array}{l}3 \\
3\end{array}$ & $\begin{array}{l}2 \\
3\end{array}$ & $\begin{array}{l}1 \\
0\end{array}$ \\
\hline U. americana (seedlings) & $4 \mathrm{yr}$ & $\begin{array}{l}\text { Aggressive } \\
\text { Non-aggressive }\end{array}$ & $\begin{array}{l}40 \\
40\end{array}$ & $\begin{array}{l}15 \\
32\end{array}$ & $\begin{array}{l}2 \\
0\end{array}$ \\
\hline
\end{tabular}

affected, contrary to experience elsewhere. In the United States $^{2}$, for example, more than $90 \%$ of American elms that were diseased throughout the crown and were not killed in the first year died subsequently as a result of the passage of the fungus (Ceratocystis ulmi) from one annual ring to the next, either in the root system and lower trunk or possibly in the crown, and not because of reinfection by the insect vectors. Following the report of the presence of an unusually aggressive strain of $C$. ulmi in the current severe outbreak areas in Britain $^{3}$, we have set out to test whether the earlier conclusions ${ }^{1}$ about recovery in native elms are still valid.

A study of young English elm (Ulmus procera) about $5 \mathrm{yr}$ old and 2-3 $\mathrm{m}$ in height was made in early June 1972, before the main period of beetle emergence, in an area (Frensham, Surrey) where aggressive isolates of the fungus had earlier been obtained. Eleven trees, infected in the previous year and showing fresh foliar symptoms, were examined. In ten of destroyed. This recommendation is based on two major points: first, only severely affected trees act as a major breeding site for the beetle; and second, there is a good chance that less severely affected trees will recover.

The first reason remains valid but the second may now be questioned at least in the severe outbreak areas where the aggressive strain is prevalent.

\section{A. BURDEKIN}

J. N. GiBBs

Forestry Commission Research Station, Alice Holt Lodge, Wrecclesham, Farnham, Surrey

Received September 6; revised September 22, 1972.

1 Peace, T. R., Bull. For. Comm., Lond., 33 (1960).

2 Banfield, W. M., Phytopath. Z., 62, 21 (1968).

${ }^{3}$ Gibbs, J. N., Heybroek, H. M., and Holmes, F. W., Nature, 236, 121 (1972).

${ }^{4}$ Gibbs, J. N., and Howell, R. S., Forest Rec., Lond., 82 (1972). 